\title{
MENGAJAR GRAMMAR DENGAN PERMAINAN ULAR TANGGA UNTUK MENINGKATKAN KOMPETENSI BERBICARA DAN MENULIS
}

\author{
Oleh: Erna Pujiasih \\ SMA Negeri 1 Bantul \\ Email: erpujiasih@gmail.com
}

\begin{abstract}
This paper discusses about the teaching strategy in teaching grammar with board game of snake and ladder to increase the speaking and writing competence. More specifically, the paper presents how to teach use game can increase the speaking competence in learning English. Teaching grammar is one the challenging for teacher to make the students competence in speaking and writing. Teaching English by using media of board game (snake and ladder) is interesting to teaching speaking and writing. This activities make the students more understand and increasing the speaking and writing use future tense. This game is media that simple and amusing for the students. It can be found that from the observation, questioner and practicing writing and speaking in the learning English by using game of snake and ladder. From the data of questioner, it shows that all of student answer that media board game can improve the student's competence in speaking and writing in understanding the grammar of future tense. It is found that the students get enjoy, interesting, learning by playing, effective, understanding, creative thinking and remember the material. Using game of snake and ladder to teach speaking and writing competence increase the students in speaking skill. This media is good and interesting for students to make the students fluent and understand the grammar. This media is not only simple but also give many advantages and effective in teaching English.
\end{abstract}

Keyword: teaching, grammar, game of snake and ladder, enjoying, understand

\section{PENDAHULUAN}

Di era kmunikasi global ini kemampuan berbicara dan menulis bahasa Inggris sangat penting untuk dimiliki oleh warga negara Indonesia sebagai bagian dari Masayarakat Ekonomi Asia. Kemampuan berbicara sangat dibutuhkan untuk berkomunikasi dengan negara lain. Kompetensi berbicara salah satu kompetensi dari empat kompetensi yang harus dimiliki/ dikuasai oleh siswa. Untuk berbicara dan menulis bahasa Inggris, grammar (tata bahasa) sangat dibutuhkan untuk menghasilkan kalimat yang baik, dan materi grammar termasuk materi yang sulit bagi siswa untuk memahami dan menggunakannya.

Dari data siswa 122 siswa ditemukan bahwa 102 mempunyai kesulitan dalam belajar Inggris khususnya grammar (tata bahasa), kosakata 85 siswa, berbicara 53 siswa, mendengarkan 53 siswa, pengucapan 19 siswa dan menulis 12 siswa. Dari data tersebut grammar merupakan masalah yang paling sulit dalam belajar bahasa Inggris.
Banyak siswa didapatkan kesulitan ketika mereka berbicara dan menulis terutama dalam penulisan grammar (tata bahasa). Mereka mengatakan bahwa grammar itu membosankan untuk dipelajari dan dimengerti. Untuk memperbaiki dan meningkatkan grammar dalam menulis dan berbicara, guru harus membuat kegiatan yang kreatif dan menyenangkan. Sehingga siswa tidak bosan dan kesulitan dalam mempelajari bahasa Inggris. Salah satu media yang sederhana menyenangkan dan menarik yaitu dengan game ular-tangga. Bagaimanakah game ular-tangga dapat meningkatkan kompetensi berbicara dan menulis yang akan digunakan dalam kegiatan mengajar?

Proses belajar dan mengajar yang menarik membutuhkan kegiatan yang menarik dan menyenangkan bagi siswa. Mengajar grammar butuh kreatifitas agar siswa tertarik dan dapat memahaminya. Apakah media yang sesuai untuk mengajar grammar? Apakah media game ular tangga dapat meningkatkan 
kemampuan berbicara dan menulis pada siswa? Apa yang siswa peroleh dalam perbaikan kemampuan berbicara dan menulis? Bagaimana kegiatan yang dilakukan dalam menggunakan game ular tangga?

\section{TINJAUAN PUSTAKA}

\section{Media Game Ular Tangga dalam Mengajar Bahasa Inggris}

Pada bagian ini mendiskusikan tentang arti game, keuntungan game, mengajarkan grammar (tata bahasa), mengajarkan berbicara dengan "game ular-tangga". Untuk meningkatkan ketrampilan berbicara kita butuh metode dan media yang digunakan dalam mengajar. Salah satu yang menarik yaitu dengan game ular tangga yang mana dulu masih anak-anak pasti pernah bermain dengan game ular tangga ini. Menurut Hoby (1995, 486) mendefinisikan game adalah kegiatan yang digunakan untuk memperoleh kesenangan. Oleh karena itu game dapat didefinisikan suatu alat yang digunakan untuk menarik motivasi siswa untuk menyertai proses belajar dan mengajar karena game dapat membuat siswa lebih fokus dalam belajar, siswa tidak merasa bahwa mereka belajar. Game juga membuat siswa untuk menggunakan pengalaman baru dengan bahasa asing yang tidak seperti belajar materi yang dipelajari. Game merupakan metode yang akan memberikan banyak manfaat untuk guru dan siswa yang lain. Buckby (1994 hal 82) mengatakan manfaat game yaitu untuk menarik siswa untuk belajar bahasa Inggris karena dengan game ini menyenangkan dan membuat mereka untuk bereksperimen, menemukan dan berintraksi dengan lingkungannya yaitu:

a. Game menembah variasi pada pelajaran dan meningkatkan motivasi dengan menyediakan tambahan untuk mencapai target bahasa yang dikuasi. Banyak anakanak antara 4 sampai 12 tahun khususnya anak muda, belajar bahasa tidak akan menjadi factor kunci dari motivasi. Game dapat memberikan stimulus ini Buckby(1994,P82)

b. Konteks game membuat bahasa asing bermanfaat segera pada anak-anak, Ini memberikan target bahasa yang akan dikuasai.Game memberikan alasan untuk mau berbicara meskipun untuk siswa yang segan/ tidak mau berbicara.

c. Melalui bermain game siswa dapat belajar Bahasa Inggris dengan cara anak belajar bahasa ibunya tanpa menyadari bahwa mereka belajar tanda stress, mereka juga dapat belajar banyak.

d. Siswa yang pemalu juga dapat berpatisipasi dengan baik.

e. Membuat kelasmu menjadi hidup melalui display yang menarik, display pekerjaan siswa dan yang lainnya. Kelas bahasa ramai dengan bahasa Inggris itu baik karena ini akan membuat kelas lebih hidup dalam mempraktikan bahasa Inggris.

f. Memotivasi siswa untuk belajar Inggris dengan menggunakan kegiatan belajar yang menarik dan menyenangkan. Seperti kerja proyek, game, drama. Ini berarti bermain sambil belajar.

g. Membuat suasan hangat dan menyenangkan dimana siswa dan guru dapat saling kerja sama. Guru membuat suasana yang baik di kelas dan siswa menjadi tertarik.

h. Membantu siswa mengembangkan alasan individu untuk belajar Bahasa Inggris. Contohnya dengan mendorong kegiatan siswa diluar sekolah seperti sahabat pena, proyek dan membaca buku cerita.

i. Menjadikan belajar Bahasa Inggris menyenangkan dan menjadi ingatan yang menyenangkanmu dan siswa terpengaruh dengan sikapnya dalam belajar bahasa. sebagai penyaring yang efektif, Ini berarti guru-guru harus mencoba untuk meminta siswa belajar yang menyenangkan ( belajar sambil bermain). Ingat bahwa guru mempengaruhi sikap dalam belajar bahasa. 
j. Jangan cemas membuat kesalahan. Dorong dan yakinkan siswa merasa nyaman dan tidak takut. Ini berarti guru tidak menyalahkan langsung pada siswa, guru harus memberikan dorongan untuk siswa ketika memperbaiki kesalahannya.

k. Berbicara banyak pada mereka dalam bahasa Inggris khususnya tentang sesuatu yang mereka dapat lihat. Guru harus mengajar siswa dengan menggunkan Bahasa Inggris, khususnya tentang sesuatu disekitar.

1. Bermain game, menyanyikan lagu, menyampaikan irama dan bernyanyi bersama. Ini berarti guru mempinyai ketrampilan dalam memainkan game, menyanyikan lagu dan lain sebagainya agar siswa senang dan tertarik untuk belajar.

m. Membicarakan teori yang sederhana dalam Bahasa inggris menggunakan gambar, dengan suara yang bernacam-macam.

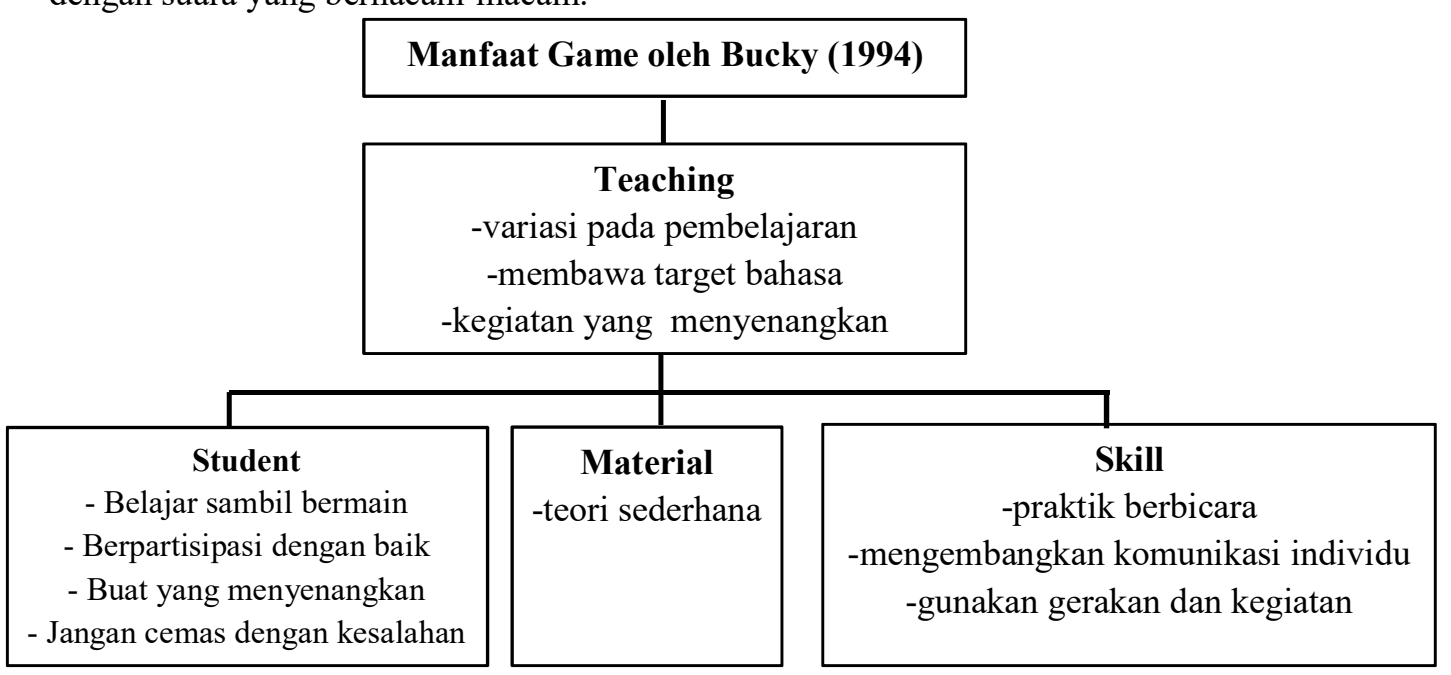

Gambar 1. Manfaat game menurut Bucky

Mengajarkan Grammar yang Menarik

Mengajarkan grammar dilakukan sebagai hasil yang telah dikerjakan siswa contohnya ketika siswa mempelajari bahasa dalam sebuah teks dalam belajar membaca atau mendengarkan. Masalah grammar muncul tanpa disadari ditengah belajar mengajar dan kita harus sesuai dengan yang dibahas. Mengajar grammar berkembang langsung dari tugas siswa yang dilakukan siswa atau telah dilakukan siswa sebagai n. Jangan cemas ketika menggunkan bahasa aslinya. Kamu dapat menjawab pertanyaan bahasa asalkan dengan bahasa Inggris, dan kadang -kadang menggunakan kembali Bahasa inggris dan mengulang berkali-kali sehingga mereka ingat apa yang guru maksudkan.

o. Dengan spontan menggunakan bahasa baru tapi tidak takut untuk menambahkan sesuatu yang baru untuk menggunakan kata-kata yang belum tau ketika mengingat materi terakhir.

p. Merencanakan pembelajaran dengan kegiatan yang bervariasu kadang tenang, ramai berdiri dan berpindah. Guru harus mendemonstrasikan mengajarnya dengan beberpa kegiatan, kadang-kadang guru duduk, berdiri didepan atau dibelakang siswa. 
yang menarik dengan papan kertas game ular tangga. Kegiatan game ular-tangga ini sangat menarik dan menyenangkan. Siswa belajar grammar sambil bermain game ular-tangga sehingga siswa tidak merasa bosan dan jenuh.

\section{Mengajar Grammar dalam Kegiatan Kelompok dengan Game dalam Meningkatkan Kompetensi Berbicara dan Menulis}

Kegiatan belajar dan mengajar yang dilaukan dengan berkelompok di kelas menjadi beberapa kelompok. Kelompok mendorong setiap siswa untuk ikut serta dalam kegiatan kemudian mereka bersama-sama untuk berbicara dan ini lebih mudah bagi siswa untuk saling berkomunikasi dengan kegiatan yang menyenangkan di kelas.

Mengajar berbicara dikelas salah satu kegiatan yang menantang karena guru harus mendorong dan memotivasi siswa untuk berbicara bahasa Inggris. Salah satu cara yang guru lakukan yaitu dengan media game ulartangga. Game ini harus dilakukan dengan berkelompok. Sehingga kelompok merupakan cra efektif untuk dilakukan kegiatan game. Untuk mengajarkan berbicara pertama guru dapat meminta siwwa untuk mendengarkan lagu yang berhubungan dengan grammar yang dipelajari, misalnya past tense, future tense. Kemudian siswa melengkapi lirik lagu. Setelah itu siswa diminta mencari kalimat dari grammar yang dipelajari. Siswa mendiskusikan dengan temannya untuk menganalisis bagianbagian kalimat tersebut.

Guru menerangkan grammar yang didiskusikan baik itu fungsi dan penerapannnya dalam membuat kalimat. Setelah siswa jelas bentuk grammar tersebut kemudian guru mngelompokkan siswa dalam kelompok yang terdiri dari 5 siswa. Kemudian siswa bermain game dengan menjawab pertanyaan dari dalam game ular tangga tersebut. Kegiatan ini seru dan menyenagkan karena siswa dapat naik ataupun turun berdasarkan game yang dilakukan oleh masing-masing pemain. Mereka merasa senang tanpa merasa kesulitan dalam belajar grammar. Grammar yang dipelajari dan telah dipraktikan tersebut game grammar dengan materi (Future Tense atau Expressing Intention). Kegiatan ini bermanfaat bagi siswa dalam kegiatan belajar. Siswa bisa mengembangkan kompetensi dalam berbicara dan mendengarkan dengan belajar dan sambil bermain.

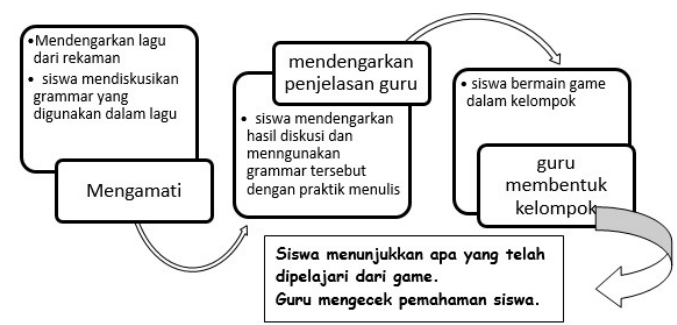

Gambar 2. Kegiatan belajar dan mengajar

\section{PEMBAHASAN}

Mengajar grammar menggunakan game membuat siswa senang dengan belajar bahasa Inggris. Kelas menjadi menarik jika jika guru mendesain pembelajaran dengan media tersebut. Kegiatan berbicara dalam kelompok dengan game memotivasi siswa untuk mau berbicara bahasa Inggris.

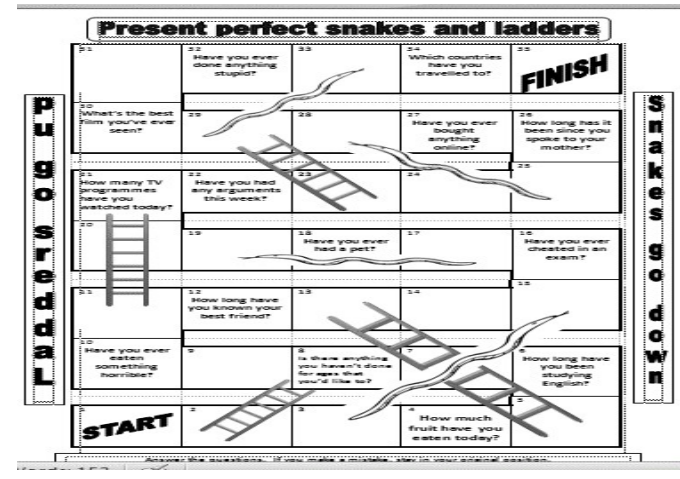

Gambar 3. Game ular tangga

Dari data kuesener 100 siswa didapatkan data bahwa siswa yang yang pernah menggunakan game ini $20 \%$ dan $80 \%$ siswa belum pernah menggunakan game ini. Ini berarti media ini masih jarang digunakan oleh gurur. Siswa juga mengatakan bahwa yang pernah itu kebayakan karena diajarkan di tempat kursus bahasa inggris dan tidak didapatkan di sekolah formal. 
Dari hasil penelitian didapatkan pendapat siswa terhadap kegiatan belajar bahasa Inggris dengan menggunakan game ular tangga ini adalah:

a. Menyenangkan dan menarik

b. Tidak bosan

c. Bagus/ baik

d. Menarik

e. Bermanfaat

f. Belajar sambil bermain

g. Menambah kosa kata baru

h. berpikir kreatif

i. Membantu memahami belajar grammar

j. Efektif

k. Komunikatif dan dapat bersosialisasi

1. Inovatif

Dalam kegiatan beajar dan mengajar grammar, siswa dibuat berkelompok misalnya satu kelompok 5 atau 6 sehingga siswa saling dapat berkomunikasi satu dengan yang lainnya. Dengan kegiatan berkelompok dapat meningkatkan dan memperbaiki kompetensi berbicara. Dari kegiatan berkelompok dengan media game ular tangga siswa juga mendapatkan banyak manfaat yaitu:

a. Siswa merasa santai dalam belajar

b. Siswa mengatakan bahwa game ini merupakan keagiatan belajar yang bervariasi.

c. Siswa dapat membuat kalimat dengan spontan / langsung.

d. Siswa dapat saling berbagi satu dengan yang lain dalam kelompok.

e. Siswa mampu berpikir kreatif karena mereka harus menjawab secara langsung.

f. Siswa berlatih berbicara

g. Siswa berbicara dan menjawab pertanyaan dengan mudah

h. Siswa dapat bertambah kosakatanya

i. Siswa berpendapat bahwa belajar dengan game ular tangga ini sederhana dan menyenangkan

j. Siswa semakin jelas dan lebih memahami grammar yang dipelajari.

k. Siswa dapat saling mengoreksi bila ada kesalahan dalam penggunaan grammar.
Dari data kuesioner tersebut jelas bahwa mengajarkan grammar dengan media game ular-tangga sangat bermanfaat bagi siswa untuk meningkatkan dan memperbaiki kompetensi berbicara. Kegiatan ini membuat mereka senang dalam mempelajari Bahasa Inggris. Mereka dapat berkmunikasi dan praktik dalam berbicara bahasa Inggris. Media game ular tangga ini efektif untuk digunakan di dalam kelas dan bisa digunakan di luar kelas. Media ini juga dapat membantu siswa meningkatan kompetensi berbicara.

Mengajarkan grammar dengan game ular tangga juga meningkatkan siswa dalam memahami kalimat dengan grammar yang dipelajari. Pendapat siswa tersebut adalah:

a. Siswa memahami grammar yang dipelajari

b. Siswa dapat saling mengoreksi satu dengan yang lain.

c. Siswa tidak bosan dalam belajar grammar.

d. Siswa menjadi senang dalam mempelajari grammar.

$e$. Siswa dapat berlatih dalam menerapkan grammar.

f. Siswa dapat menulis kalimat dengan grammar yang dipelajari

g. Siswa mengatakan bahwa game ini sederhana, efektif dan bervariasi

h. Siswa dapat mengingat rumus yang dipelajarinya dari bermacam-macam bentuk tenses dari grammar

Dari data tersebut dapat disimpulkan bahwa game grammar ular tangga dapat membantu siswa dalam mempelajari grammar sehingga siswa dapat membuat kalimat tanpa merasa kesulitan dalam menerapkan kompetensi menulis. Siswa juga lebih baik dalam menuliskan kalimat dengan tata bahasa yang tepat.

Untuk memotivasi proses belajar dan mengajar, guru juga mempersiapkan hadiah yang dapat diberikan bagi siswa yang menjadi pemenang dari game ular-tangga tersebut. Siswa senang dan tertarik dengan game yang berwarna-warni dan berbagai macam pertanyaan yang terdapat dalam game ular tangga. 


\section{KESIMPULAN}

Mengajar grammar merupakan tantangan bagi guru dalam mengajarkan Bahasa Inggris. Kegiatan ini tidak menarik jika guru tidak mendesain dan mempersiapkan dengan kegiatan yang kreatif dan variatif. Salah satu media mengajar yang menarik dan menyenangkan untuk mengajar adalah game ular tangga. Media ini sederhana, murah, menarik dan menyenangkan. Siswa dapat terbantu dengan media ini dalam belajar grammar. Ini dapat digunakan sebagai kegiatan mengajar bahasa dikelas.

Guru dan siswa mendapatkan banyak manfaat dalam menggunakan media game ular tangga karena siswa dapat memperoleh perbaikan dengan media ini. Siswa juga lebih memahami penggunakaan grammar yang dipelajari sehingga dapat memperbaiki dan meningkatkan kompetensi berbicara dan menulis. Dari data observasi, kuesioner, praktik bermain game ular tangga ini mendapatkan banyak manfaat. Ini dapat dilakuka dengan menyiapkan pengajaran dengan media mendengarkan dan game ular tangga sesuai dengan materi yang dipelajari.

$\begin{array}{llrr}\text { Kegiatan } & \text { ini dimulai } & \text { dengan } \\ \text { mendengarkan lagu } & \text { setelah } & \text { siswa } \\ \text { mendiskusikan grammar dari lagu yang } & \text { gram } \\ \text { dipelajari. Setelah itu guru dan siswa } \\ \text { mendikusikan penggunaannya, kemudian } \\ \text { siswa bermain dengan game tersebut dalam } \\ \text { kelompok. }\end{array}$

Kegiatn belajar mengajar dengan game ini membuat siswa senang, tertarik, praktik berbicara, kreatif berpikir, tidak bosan, komunikatif, mampu membuat kalimat, menambah kosakata, dan mengerti grammar. Kegiatan mengajar yang dilakukan secara berkelompok membuat siswa senang, santai dalam berkomunikasi, berdiskusi, membenarkan yang salah dan saling membantu satu dengan yang lain.

Game ular tangga dalam bentuk grammar akan meningkatkan kompetensi siswa baik dalam berbicara dan menulis. Siswa menajdi senang dalam kegiatan belajar dan siswa mendpatkan banyak manfaat dari kegiatan tersebut. Siswa mampu menuliskan kalimat dengan benar Karena mereka telah memahami grammar yang dipelajari tersebut. Pembelajarn dengan game ular tangga ini efektif, sederhana dan komunikatif untuk diterapkan. Guru menggunkan ini sengai kegiatan yang bervariasi sehingga siswa tidak merasa jenuh dan bosan dengan media yang monoton atau tidak menarik. Game ular tangga dapat meningkatkan dan memperbaiki kompetensi berbahasa dari mendengarkan, berbicara dan menulis.

\section{DAFTAR PUSTAKA}

Buckby, Michael. 1994. Games for Language Learning. Australia: Cambridge University Pres.

Hornby A. S 1990. Oxford Advance Learner's Dictionary of Current English. London: Oxford University Pres.

Jeremy, Harmer. 2007.The Practice of English Language Teaching. England Pearson Education Limited. 